Bird Conservation International (2003) 13:97-114. (C) BirdLife International 2003

DOI: $10.1017 /$ S0959270903003095 Printed in the United Kingdom

\title{
Conservation options for the Critically Endangered Seychelles Black Paradise-flycatcher Terpsiphone corvina
}

\author{
DAVE CURRIE, MIKE HILL, JAMES MILLETT, RACHEL BRISTOL, JOHN \\ NEVILL and NIRMAL J. SHAH
}

\begin{abstract}
Summary
Seychelles Black Paradise-flycatcher Terpsiphone corvina is found almost exclusively on the $10 \mathrm{~km}^{2}$ island of La Digue. It is currently considered the second rarest endemic bird in the Seychelles, using the criteria of total population and number of discrete populations. Research reassessing the habitat requirements of the flycatcher was conducted on La Digue from 1999 to 2001. This work was conducted in parallel with assessment and ranking of the suitability of medium-sized islands of the inner Seychelles archipelago for avian ecosystem restoration, using biological, geographical and anthropogenic criteria. Predator eradications on several islands have led to a reduction in the range of alien predators, and future eradications are planned. These developments combined with the findings of recent ecological research and a novel assessment of many islands in the archipelago have led to the opportunity for a reassessment of conservation options for Seychelles Black Paradise-flycatcher. This paper discusses and prioritizes strategies to increase the range and total population and hence improve the conservation status of this species.
\end{abstract}

\section{Introduction}

The granitic Seychelles consists of 40 islands $\left(\right.$ c. $\left.230 \mathrm{~km}^{2}\right)$ in the western Indian

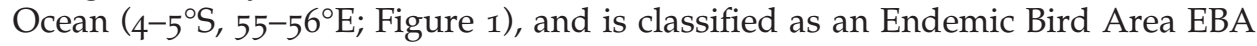
(Stattersfield et al. 1998). Human colonization in the 1770s, followed by introduction of plantation agriculture resulted in severe environmental degradation, and the recorded extinction of at least two endemic land bird taxa (Diamond 1984). Of the remaining 12 extant endemic taxa, four are listed as Critically Endangered on the basis of small population and/or severely restricted range (BirdLife International 2000). Factors implicated in the continued decline or slow recovery of the surviving populations of endemic birds include ongoing habitat degradation and the presence of alien species.

Seychelles Black Paradise-flycatcher Terpsiphone corvina (Newton 1867) was historically recorded on at least five of the inner-granitic islands in the Seychelles (see Table 1). In the late nineteenth and early twentieth century it experienced a marked reduction in its range, attributed predominantly to the large-scale clearance of native broad-leaved woodland on coastal plateaux due to the introduction and expansion of plantation agriculture, and the establishment of alien mammals. 


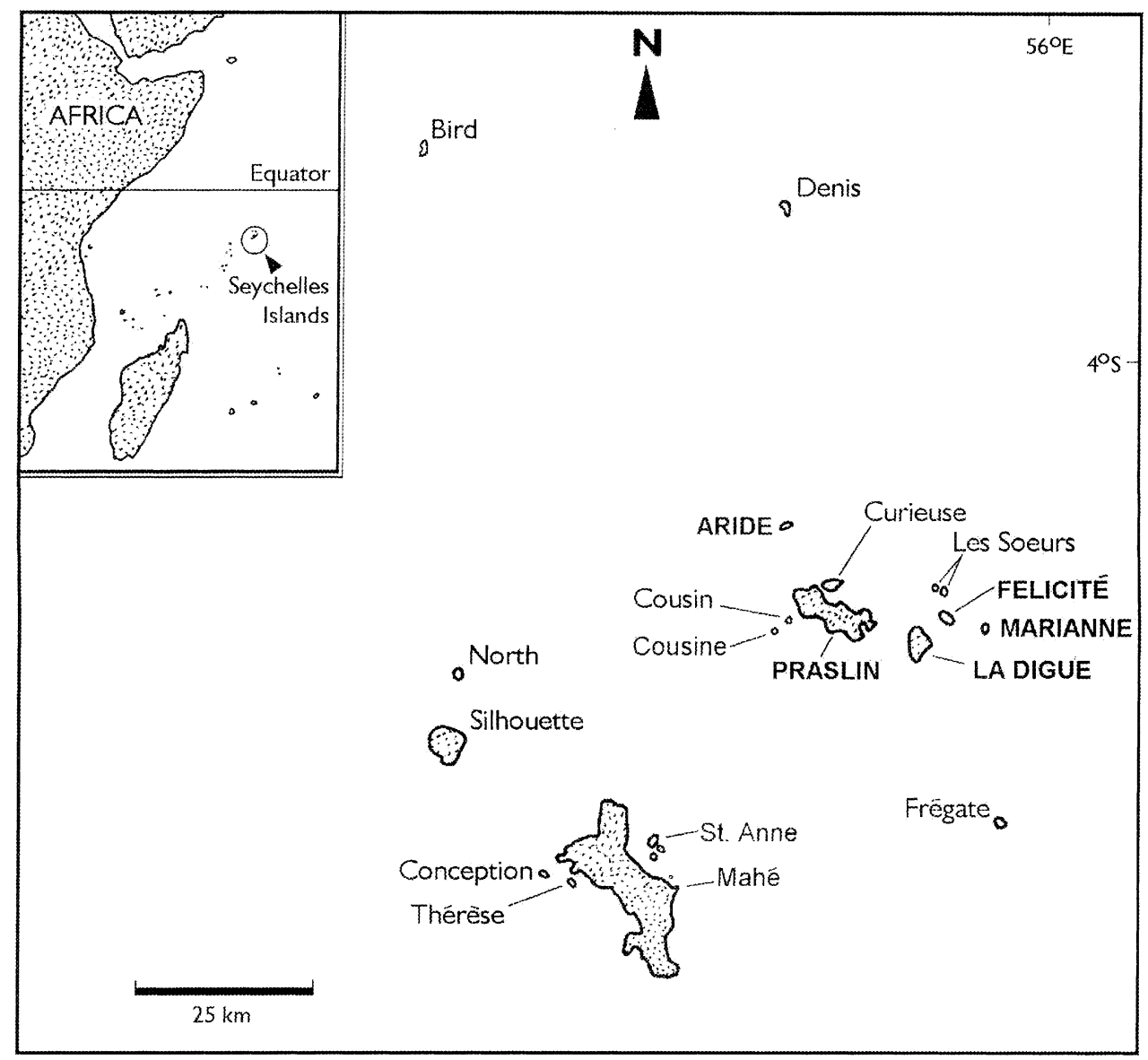

Figure 1. Map showing Seychelles inner archipelago. Islands titled in bold upper case were within the flycatcher's documented historical range.

Table 1. Documented historical range of Seychelles Black Paradise-flycatcher showing dates of last known records and population estimates.

\begin{tabular}{llll}
\hline Island & Population & Year & Reference \\
\hline Felicité\# & - & $1906^{\mathrm{EX}}$ & Nicoll (1906) \\
Marianne\# & - & 1936 & Vesey Fitzgerald (1940) \\
& c. 3 & 1998 & Parr and Shah (1998) \\
Aride & c. 3 & 2000 & Hill (2001) \\
Praslin & - & $1907^{\mathrm{EX}}$ & Diamond (1984) \\
& c. 3 & 1978 & Watson (1984) \\
La Digue & c. 3 & $19899^{\mathrm{EX}}$ & Gerlach (1997) \\
& 28 & 1965 & Gaymer et al. (1969) \\
& $50-90$ & 1971 & Beamish (1972) \\
& 66 & 1977 & Watson (1981) \\
& 73 & 1988 & Watson (1988) \\
& $138(150-200)$ & $1996-97$ & Rocamora (1997) \\
\hline
\end{tabular}

- No data; \# sporadic reports of solitary individuals 1970s-1990s; ${ }^{\mathrm{EX}}$ Extinct 
The species was described from specimens collected on Praslin, the second largest island in the Seychelles (Newton 1867), where a population survived into the late twentieth century; by the 1980 os this population had dwindled to a few birds (Watson 1984) and by c. 1989 it was extinct (Gerlach 1997). This left only one known population on the island of La Digue. In 1998, a few individuals were observed on the nearby island of Marianne, after a recorded absence of 60 years (Parr and Shah 1998).

Research on the ecology of the flycatcher in the 1980s highlighted the importance to the species of both native broad-leaved woodland (primarily Takamaka Calophyllum inophyllum and Badamier, also known as Indian Almond, Terminalia catappa) and wetland areas (Watson 1981, 1988, 1991; see also Bullock et al. 1988). This research led to the implementation of a series of conservation measures on La Digue. These were: (i) the creation of a reserve (area 8 ha) in 1991, which contained one of the few stands of mature forest on the western plateau and $c$. $20 \%$ of the world population at the time, and its subsequent wardening and management (Shah 1995a), (ii) controls on the felling of both Takamaka and Badamier outside the reserve through the issue of permits, (iii) increased public awareness and education, and species protection - catapults were banned in 1991. In addition, the population and its breeding success were monitored (Rocamora 1997). These measures were followed by a further purchase of $c .11$ ha of land, predominantly marshland adjacent to the existing reserve, in 19992001.

Reassuringly, the population on La Digue has more than doubled in the last 12 years from c. 60-70 individuals in 1978-1988 (Watson 1991) to 69 confirmed territories in the late 1990s (c. 150-200 individuals; Rocamora 1997), the majority (c. $80 \%$ ) of which are located on the island's 220 ha western plateau (Watson 1991, Rocamora 1997). The reasons for this increase are unclear: paradoxically, it has occurred concurrently with increased development and a documented loss and fragmentation of native broad-leaved woodland habitat (Rocamora 1997, Marshall 1997, Neufeld 1998) and in the presence of a suite of alien predators.

Since the only viable population of the flycatcher is located on one island, and is therefore potentially vulnerable to extinction, establishment of additional populations on other suitable islands is considered important in improving its conservation status (e.g. Watson 1984, 1991, Hambler 1992, Rocamora 1997, Marshall 1997). However, to date there has been insufficient quantitative data on the suitability of other islands, and the choice of apparently suitable islands was limited. Suitable islands are defined as those with no or few alien predators to reduce adult survivorship and/or limit reproductive success, and with extensive natural or native-dominated forest. Unlike some other globally threatened Seychelles endemic landbirds, the flycatcher appears to be able to persist in the presence of several alien predator species including black rat Rattus rattus, brown rat R. norvegicus and domestic cats Felis catus, probably due to locating its nests on the end of thin down-hanging branches, making them less vulnerable to predation (c.f. Watson 1991). However, a small founder population may be more vulnerable to the impacts of nest and adult depredation.

Alien predators were introduced to most of the inner islands and only five islands larger than 20 ha, typically with extensively modified vegetation, have remained completely or partially predator free. Cousin ( $27 \mathrm{ha})$, Cousine ( $25 \mathrm{ha})$ 
and Aride (68 ha) remained rat free; Frégate (219 ha) was colonized by brown rats in 1995 (Thorsen et al. 2000), which were eradicated in 2000 (Millett 2001); and Bird (101 ha) was colonized by black rats in 1967, which were eradicated in 1995 (Feare 1999). Cats were eradicated from Aride (1930), Frégate (1982; Collar and Stuart 1985) and Cousine (1986; V. Laboudallon, pers. comm). Native vegetation communities have been restored on Cousin, Cousine and Aride; the latter is the only island currently free of rats and cats within the flycatcher's documented original range (Diamond 1984).

In 1999-2000, BirdLife Seychelles conducted an assessment of 10 islands in the Seychelles inner archipelago in collaboration with the Seychelles Government. One of the aims of this study was to determine their suitability for translocation of endemic landbird species, including the flycatcher (Hill 2002). Research examining flycatcher habitat requirements was simultaneously conducted on La Digue using comparable methods to those used during the island assessments. In light of recent research this paper discusses the future management options for the flycatcher on La Digue and future considerations for its establishment on other islands.

\section{A re-evaluation of flycatcher habitat requirements}

Recent research on La Digue has further emphasized the importance of native broad-leaved (Takamaka and Badamier) plateau forest in flycatcher habitat requirements. It has been shown that territories contain significantly more native plateau tree species than predicted by their availability on the plateau; that native tree species are used significantly more for foraging and nesting than predicted by their availability within territories; and that there is an inverse correlation between the density of native tree species and territory size (Currie et al. in press).

The association between flycatchers and water, proposed due to the presumed importance of invertebrate prey with an aquatic life-stage (c.f. Watson 1991) is less clear, and may in fact have been overemphasized, at least on La Digue plateau, due in part to the non-random association between the distribution of native broad-leaved forest habitat and both semi-permanent (seasonal) and permanent water bodies (Currie et al. in press). Only marginal beneficial effects of proximity to water bodies have been detected on the abundance of invertebrates (assessed by aerial sampling and counts of insects on foliage), while no differences have been detected on flycatcher foraging or breeding success relative to distance to water (Currie 2002, Currie et al. in press). Similarly, the first island-wide survey of the flycatcher on La Digue conducted in 2001 indicated that flycatchers were not necessarily associated with either coastal plateau or wetland areas; the presence of high canopy (native) forest was the only significant factor associated with flycatcher distribution (Currie 2002).

In addition, it has been shown that the majority (66\%) of identified invertebrate prey ( $n=341$; July 1999-May 2000) are not directly dependent on water and less than $10 \%$ of identified prey items are dependent on water at any stage of the life cycle. Most common prey are Orthoptera and Lepidoptera (together comprising $66 \%$ of identified prey items: Currie et al. in press). It is worth noting that although the two remnant populations in the 1970s (on Praslin and La Digue) were in native plateau forest associated with wetlands, the flycatcher was origin- 
ally recorded on at least three other islands (Aride, Marianne, and Félicité; Nicoll 1906, Vesey-Fitzgerald 1940, Diamond 1984), which have wetlands that are small and currently seasonal (Bowler and Hunter 2000, Hill in press). The presence of flycatchers on these islands was consistent with results of the random point survey on La Digue (Currie 2002).

\section{Demographics of the La Digue plateau population}

Measures of flycatcher breeding success (calculated from proportions) have been very variable, ranging from $24 \%$ (Watson 1981) to more than $90 \%$ (Rocamora 1997). Data from more than 250 nesting attempts monitored constantly over a two-year period (June 1999-June 2001), indicated that annual breeding success was c. 35\% (Currie 2002, Currie et al. in press), calculated using the Mayfield method (Mayfield 1961, 1975). The main reason for nesting failure appeared to be depredation, although in the majority of cases nest predators were not identified. Although this means that the relative impact of alien and native predators was unresolved, remains at depredated nests indicated that birds and animals (including Rattus spp., most likely $R$. rattus) were nest predators. Intense mobbing of the endemic Seychelles Bulbul Hypsipetes crassirostris, native Greenbacked Herons Butorides striatus and, to a lesser extent, the introduced Common (or Indian) Mynah Acridotheres tristis by adult flycatchers, indicate that they may be perceived as potential nest predators (Nature Seychelles unpubl. data; see also Watson 1991). Bulbuls were subsequently confirmed as nest predators using video monitoring (Currie 2002).

Adult mortality in 1999-2001 was c. 21\% (Currie 2002). There are no quantitative data on predators of adult and juvenile birds, although cats have been observed to attack and kill adults, while some females are killed on the nest, or lost around the time of nest failure, indicating that in some instances nest and adult predators are the same (Currie 2002). Control of potential (nest and adult) predators might increase breeding success (e.g. Robertson et al. 1994), but this is probably impractical on La Digue due to the close association between many flycatcher territories and human habitation and activities.

\section{Future management of the La Digue population}

The major threat to the flycatcher on La Digue appears to be the loss of native broad-leaved plateau woodland primarily associated with private house development, plantation agriculture, and demands for timber (Watson 1991, Rocamora 1997, Currie 2002, Currie et al. in press). The flycatcher reserve (8 ha) therefore offers limited protection, as more than $90 \%$ of territories occur outside its designated boundaries. Habitat loss and degradation has been accelerated by Takamaka wilt disease Leptographium (Verticillium) calophylli. This fungus, which causes extensive rapid dieback and defoliation, and sometimes death of the tree, was first documented in the Seychelles in 1994 (Ivory and André 1994, Shah 1995b, Wainhouse et al. 1998) and has spread rapidly. Mortality rates are unknown but in similar outbreaks of wilt affecting other species of Calophyllum this can be high e.g. c. 50\% (Crandall 1949 in Ivory et al. 1996). In March 1999 c. $1 \%$ of Takamaka trees on 29 flycatcher territories on La Digue were infected, 
while by December 2000 c. 11\% of Takamaka trees were either dead or exhibiting acute symptoms (Hill et al. in press a.). The rapid spread of disease on La Digue is similar to that observed on other islands (Hill in press, Hill et al. in press a). To date, control measures have been ineffective; initial government policy up to 2000 was to cut and burn infected trees, but this was soon abandoned for a "wait and see" approach. Some preventative measures, including fungicidal injections have been instigated since 1999, although the effectiveness of this treatment is still unclear. In light of the rapid spread of Takamaka wilt, the area of native woodland on the plateau is likely to decrease and the surviving forest become more fragmented, at least in the short term.

Further to recommendations for the flycatcher conservation proposed by previous authors (see Watson 1991, Rocamora 1997), certain key actions seem necessary in light of recent events:

(i) Continued conservation of existing native broad-leaved forest outside the reserve;

(ii) Purchase and replanting of additional land when possible;

(iii) Monitoring of the spread of Takamaka wilt and tree mortality;

(iv) Replanting areas lost to wilt, and previously cleared areas with native tree species, e.g. Badamier T. catappa, Bois Blanc Hernandia nymphaefolia, Bois de Natte Mimusops sechellarum, and native fig species Ficus lutea/reflexa/rubra.

Badamier is a deciduous species, losing its leaves during the dry season. Mixing with other native tree species may therefore be preferable. There is evidence of reduced breeding success in proximity to the forest edge (Currie 2002, see also Watson 1991), and plantations in cleared areas and/or in areas affected by wilt should be as large as possible, but may be constrained by fragmented land tenure. Isolated patches of native trees would still have value, but would support larger and more dispersed territories. Planting of native trees within gardens could provide additional foraging habitat. However, tree choice for small private gardens will involve a number of factors other than purely conservation value e.g. ultimate tree size and aesthetic considerations.

\section{Creating additional populations}

Whilst some of the above recommendations are ongoing or planned, they are long-term actions. The most feasible option to increase both the population and range of the flycatcher in the short to medium term is to translocate individuals to other islands with suitable habitat.

\section{The constraints of the La Digue (plateau) model}

A recent island-wide survey showed that flycatchers were more widely distributed on La Digue than previously documented and were not necessarily associated with plateau (land $\leqslant 10 \mathrm{~m}$ asl) or wetland areas, although flycatcher density was c. 1.5 times higher on the plateau than upland areas (Currie 2002). Irrespective of this, there was good evidence that off-plateau birds contributed to the demographics of the island population, although in the absence of quantitative data on the ecology of off-plateau birds, translocation options at this time are best 
based on quantitative data collected on individuals from the plateau populations.

Additional constraints are imposed on island suitability, as La Digue cannot be considered a "typical" island within the Seychelles on geographical or biotic criteria: it has a large (220 ha), wide (c. $900 \mathrm{~m})$, and well-watered plateau fed by seven rivers/streams and numerous freshwater bodies. Other medium-sized islands have smaller or fragmented and narrow plateaux and are drier especially during the south-east monsoon. Due to the close association between flycatchers and Takamaka and Badamier (which are also the dominant native tree species on the western plateau), it is also difficult to assess the suitability of other forests of native and non-native tree species. This highlights the limitations in defining habitat requirements from, and basing future management decisions on only one, possibly atypical, remnant population. Other species in the genus Terpsiphone appear to have less specific habitat requirements (e.g. King et al. 1993, Johnson and Herremans 1997), but current data indicate that those of Seychelles Black Paradise-flycatcher are more conservative than other Seychelles endemic insectivorous passerines e.g. Seychelles White-eye Zosterops modestus and Seychelles Warbler Acrocephalus sechellensis (Komdeur et al. 1991, Rocamora and François 2000). Given the extreme rarity of the flycatcher on a global scale, translocations to islands that lack vegetation similar to that of the La Digue plateau would be unwise.

\section{Criteria used to assess island suitability}

Island assessments have been made that have excluded both the largest (> 1000 ha) and smallest $(<20 \mathrm{ha})$ islands, and concentrated on medium-sized islands, which offered the benefits of smaller islands. These included single ownership, small or absent human population, and the potential for eradication of introduced species and maintenance of predator-free status, whilst being large enough to support sustainable populations of endemic birds (for more details see Hill 2002). Within the size range surveyed, larger islands are likely to offer the greatest opportunity for restoration. Island suitability for flycatchers has been assessed using several criteria, in particular the area of native broad-leaved plateau forest, invertebrate abundance and predator status.

\section{Availability of suitable habitat}

On La Digue, flycatcher territories have been shown to comprise predominantly native broad-leaved woodland and range in size from 0.4 to 2.5 ha (mean 1.04 ha; Currie et al. in press). Preferred islands are therefore those that could hold the largest predicted populations, i.e. those with the largest area of native broadleaved plateau forest.

\section{Food availability}

In feeding observations conducted on La Digue (Currie et al. in press), the majority of foraging occurred in mid-canopy and involved taking invertebrate prey items from the surface of leaves (gleaning and sally-gleaning; c. 80\% of successful feeds). Counts of invertebrates on leaf surfaces are, therefore, probably a good 
indicator of food availability (Hambler 1992). Methods used for invertebrate counts on foliage were modified after Komdeur et al. (1991): all invertebrates were counted on the underside of leaves of a range of tree species and identified to order. In island assessments, trees were selected at random points across each island (at least 10 points per island). Leaf counts were made in each of the two main seasons, the drier period (June-October) dominated by south-east trade winds and the wetter north-west monsoon period (December-March). For more details see Hill (in press).

On La Digue, systematic bimonthly leaf counts (on 105 Takamaka, 105 Badamier and 90 non-native broad-leaved tree species, respectively, totalling 6,000 leaves) were conducted every two months from September 1999 to December 2000 , and revealed marked seasonality in invertebrate abundance (Nature Seychelles unpubl. data). For logistical reasons, it proved impossible to carry out sustained monthly leaf counts on assessed islands throughout the year. Therefore, comparisons of leaf counts between assessed islands and La Digue were made using data collected in the same months. Irrespective of this, seasonal inter-island variations and patchiness are still likely to make absolute comparisons of invertebrate abundance between the assessed islands and La Digue difficult. In comparative analyses of invertebrate abundance between assessed islands and $\mathrm{La}$ Digue, ants and soft bugs have been both excluded and included in measures of invertebrate availability. Their exclusion may be conservative, for example Komdeur et al. (1991) included all invertebrates when studying Seychelles Warbler. However, although it was not possible to identify the majority of small items in the diet with certainty during feeding observations, it is likely that ants (Hymenoptera: Formicidae) or soft bugs (Hemiptera: Sternorrhyncha, with the possible exception of psyllids) do not comprise a significant part of flycatcher diet, although ants may influence important prey species, for example through predation.

In general, most islands showed lower leaf counts on Takamaka and Badamier in the north-west monsoon period (November to April) than La Digue, while in the south-east monsoon (May-October) leaf count values were comparable (Appendix 1). Invertebrate numbers are likely to be affected by local environmental conditions and therefore leaf counts probably cannot be compared in absolute terms. None of the assessed islands stands out as being markedly different from La Digue. Hill (2002) concluded that since native tree species generally have higher leaf counts than introduced species (excluding ants and soft bugs), islands with the greatest potential for insectivorous birds, including the flycatcher, are those with the largest number of native trees/area of suitable habitat.

\section{Predator status}

The impact of rats and cats on endemic island faunas are well documented (e.g. Merton 1975, 1978, Bell 1978, Atkinson 1985). Available data indicate that native (Seychelles Bulbul) and alien species (cats and rats) are adult and/or nests predators and islands without these predators are therefore preferable.

\section{Climate}

The role of climate in the distribution and ecology of the species is unknown. Temperature variations are small, at least around sea level (on the coastal plateau 
most utilized by flycatchers), with an annual range in mean monthly temperatures of $2-3{ }^{\circ} \mathrm{C}$ (Walsh 1984). There is greater variation in the total annual rainfall, and its distribution through the year. Given the proposed link between standing water and food supply (Watson 1991, but see Currie 2002, Currie et al. in press), and the apparent seasonality of invertebrate density on leaves, with generally higher abundances in the rainy season (October to March; Hill in press), variations in rainfall patterns may have an ecological impact on the species. At sea level on La Digue mean annual rainfall varies between 2,026 $\mathrm{mm}$ and $2,128 \mathrm{~mm}$ (data from two sites). Rainfall records for the smaller islands of the Seychelles are incomplete (Walsh 1984) but appear generally to have lower total rainfall than the larger islands ( $1,500 \mathrm{~mm}$ to $2,000 \mathrm{~mm}$ ). This pattern is influenced by the proximity and the relative position of larger islands.

\section{Socio-economic factors}

Even where an island is deemed suitable on ecological grounds, island ownership must be stable and owners/managers have a long-term commitment to conservation. Furthermore, since translocation, like other aspects of a recovery programme is process oriented, it is important to put together a small group of stakeholders, including owners of suitable islands, La Digue residents, government, and other individuals who have a genuine demonstrable stake in the conservation of the flycatcher to discuss and agree aims. Removing flycatchers from La Digue to move to other islands is a sensitive issue as they are viewed as a "La Digue bird". Consultation with island residents is therefore important to raise local awareness of the need for translocation, possibly in the near future. This will need to involve a public relations campaign aimed at local stakeholders to alleviate their concerns, and should be instigated as soon as possible. Recent proposals to remove flycatchers were met with resistance from some stakeholders.

\section{Use of IUCN translocation guidelines}

International guidelines for translocation exist (IUCN 1998) to encourage best practice in translocations. Because of the wide-ranging nature of the guidelines, and their attempts to include all taxa in many circumstances, some of the issues raised may be of less relevance than others in individual situations, or translocation attempts. For example, one recommendation of the guidelines is that translocations should be restricted to a species' known former range, and indeed, translocations to areas outside the former range of a species generally have a lower degree of success (Griffith et al. 1989). However, in the case of Seychelles landbirds little is known about their ranges prior to Newton (1867), by which time islands and their respective habitats had already been significantly altered (Rocamora and Skerrett 2000).

The inner islands studied can be divided into four categories on the basis of present inter-island distance: the Mahé satellites (Thérèse and Conception); Praslin/La Digue satellites (Grand Soeur, Félicité, Marianne and Curieuse); the coralline islands (Bird and Denis); and North Island in a category of its own (being most closely associated with Silhouette). Only two assessed islands were within the known historical range of the flycatcher: Marianne and Félicité (Nicoll 1906, 
Vesey-Fitzgerald 1940), although it is likely that the species' range extended at least throughout the La Digue-Praslin island group. There is, therefore, no obvious conflict with IUCN guidelines with translocating flycatchers to any of the La Digue/Praslin satellites, but translocation to any other of the assessed islands in the absence of distribution data extending the known former range may be inconsistent with these recommendations. However, the restricted distribution and conservation status of the flycatcher (IUCN status Critically Endangered; BirdLife International 2000) and data deficiencies are probably sufficient justification for their translocation to any island in the inner archipelago deemed suitable, due to the limited choice of islands with suitable habitat. The interactions of flycatcher and other species of endemic birds are difficult to predict, as quantitative data on habitat requirements of other potentially competing insectivores is incomplete. Of 12 landbirds endemic to the Seychelles, six feed on invertebrates to a significant extent. Two (Seychelles Magpie-robin Copsychus sechellarum and Seychelles Swiftlet Collocalia elaphra) forage in environments very distinct from those where flycatchers feed, taking a different range of foods (e.g. Skerrett et al. 2001, Njoroge, 2002). Of the four remaining species, one (Seychelles Sunbird Nectarinia dussumieri) is widespread and not threatened, feeding to a large extent on nectar (Grieg-Smith 1980). The remaining three threatened species (Seychelles White-eye, Warbler and Fody Foudia sechellarum) probably show some overlap in diet with the flycatcher. Good data are only available for the white-eye and warbler, and indicate some degree of overlap in diet (Komdeur et al. 1991, Rocamora and François 2000), but both of these species appear able to exploit a broader range of foods and habitats than the flycatcher. Neither these species, nor the fody, occur sympatrically with flycatchers today, but qualitative data collected in the early twentieth century (e.g. Vesey-Fitzgerald 1936) indicate that flycatchers can probably coexist with other endemic passerines in suitable habitat.

\section{Evaluation of island suitability: surveyed islands}

\section{Habitat suitability}

If all islands surveyed, irrespective of predator status, are ranked on criteria deemed important for flycatchers the three top ranking medium-sized islands (on the basis of island and plateau size, and area of suitable forest habitat) are Curieuse, Denis and North (Table 1). Curieuse was also identified as potentially suitable by Watson (1981) (see also Hambler 1992 and Stevenson et al. 1997). It has extensive Takamaka-Badamier forest currently totalling some 27 ha distributed over three plateaux, much of which is close to wetland areas. It is government-owned and therefore its long-term future appears secure. As of January 2000 it was predicted to hold $10-20$ pairs without extensive habitat restoration. However, between January 2000 and January 2001 Takamaka wilt destroyed almost all the suitable habitat (2-3ha) on one plateau, which has reduced the initial predicted carrying capacity of the island. Although this plateau is isolated from the other two plateaux, based on observations on other islands (Hill 2002, Hill et al. in press a), it is likely that wilt will spread rapidly to the other plateaux. This may have serious implications for a proposed translocation and the future 
of any translocated population, and translocation of flycatchers to Curieuse can therefore only be recommended if it is preceded and subsequently accompanied by extensive habitat restoration, involving immediate replanting with other native broad-leaved plateau forest species.

Denis Island, although coralline, also emerges as very favourable for the flycatcher, primarily due to the significant area of native plateau forest ( $27 \mathrm{ha}$ ), dominated by Badamier. Few Takamaka trees occur, and although Takamaka wilt is present the impact will be minimal. The presence of a small marsh also improves its suitability, and the owners are sympathetic to conservation. The only concern is that rainfall is lower than La Digue c. 1,500 mm: coralline islands are generally drier than granitic islands, but also experience more constant rainfall due to a shorter annual dry season (Walsh 1984). It is expected to be able to hold 10-20 pairs.

North Island's suitability is due primarily to its large plateau (67 ha) with extensive marsh. It is privately owned and the owners appear to be sympathetic to conservation. However, currently there is only one small area of native plateau forest, which is also being severely affected by Takamaka wilt (Hill 2002), and significant habitat restoration would be required prior to any translocation.

Of the other islands, both Félicité and Marianne Islands lack plateaux, but do have areas of native forest, extensive in the case of Félicité (Table 2). Interestingly, although neither is associated with large or extensive wetland and/or plateau systems, both have been documented as being in the historical range of the flycatcher (Nicoll 1906, Vesey-Fitzgerald 1940). Certainly, the opportunity exists to add individuals to the existing Marianne population, which does not seem to have increased significantly since being rediscovered in 1998 (Parr and Shah 1998, Hill 2002). The small plateaux and small areas of native forest would seem to preclude consideration of translocation of the flycatcher to Thérèse, Conception, or Grand Soeur.

Table 2. Ranking of medium-sized islands in the inner Seychelles (irrespective of predator status) on criteria deemed important for flycatchers (see text). Ranks are in parentheses. Mean rank I includes all criteria, while mean rank II excludes island size.

\begin{tabular}{|c|c|c|c|c|c|c|}
\hline & $\begin{array}{l}\text { Size } \\
\text { (ha) }\end{array}$ & $\begin{array}{l}\text { Plateau } \\
\text { (ha) }\end{array}$ & $\begin{array}{l}\text { Woodland } \\
\text { (ha) }\end{array}$ & $\begin{array}{l}\text { Marsh } \\
\text { (ha) }\end{array}$ & $\begin{array}{l}\text { Mean } \\
\text { rank I }\end{array}$ & $\begin{array}{l}\text { Mean } \\
\text { rank II }\end{array}$ \\
\hline Curieuse & $286(1)$ & $74(3)$ & $27.9(1)$ & $0.7(1)$ & 1.5 & 1.7 \\
\hline Félicité & $268(2)$ & $35 \cdot 4(2)$ & o (9) & $0.2(3)$ & $4 \cdot 5$ & $5 \cdot 3$ \\
\hline Frégate $^{1 \mathrm{a}}$ & $210(3)$ & $30(6)$ & $<1(8)$ & o (4) & $5 \cdot 3$ & 6 \\
\hline North & $201(4)$ & $67 \cdot 4(4)$ & $12.2(4)$ & $0.7(1)$ & $3 \cdot 3$ & 3 \\
\hline Denis $^{3 b}$ & $140(5)$ & $140(1)$ & $27 \cdot 7(2)$ & $0.3(2)$ & 2.5 & 1.7 \\
\hline Marianne & $94.7(6)$ & $17.9(8)$ & $0.4(7)$ & $0.2(3)$ & 6 & 6 \\
\hline Grand Soeur & $84(7)$ & 17.8 (9) & $1.8(6)$ & $0.2(3)$ & 6.3 & 6 \\
\hline Birdıb & $82(8)$ & $82(2)$ & $12.6(3)$ & o (4) & $4 \cdot 3$ & 3 \\
\hline Therese & 73.9 (9) & $10.2(11)$ & o (9) & $0.3(2)$ & 7.8 & $7 \cdot 3$ \\
\hline Aride $^{1 \mathrm{a}}$ & $68(10)$ & $5.2(12)$ & $3(5)$ & $0.3(2)$ & $7 \cdot 3$ & 6.3 \\
\hline Conception $^{4}$ & $60.3(11)$ & $13.1(10)$ & o (9) & o (4) & 8.5 & $7 \cdot 7$ \\
\hline Cousin $^{1}$ & $27(12)$ & $22(7)$ & 0.7 (9) & $0.2(3)$ & 7.8 & 6.3 \\
\hline Cousine $^{1 a}$ & $25.7(13)$ & $6(13)$ & $>1(8)$ & o (4) & 9.5 & 8.3 \\
\hline
\end{tabular}

${ }^{1}$ Rat and cat free; ${ }^{2}$ Rat free; ${ }^{3}$ Cat free; ${ }^{4}$ Rattus norvegicus; ${ }^{a}$ Not surveyed; ${ }^{b}$ Coralline 


\section{Presence of predators}

Only two of the surveyed islands (Cousin and Bird) were rat, cat and bulbul free. Although Hill (2002) concluded that both met some of the criteria to support populations of flycatchers, both lack Takamaka-Badamier forest and therefore do not meet the conservative selection criteria. Furthermore, the native broad-leaved forests on both islands comprise extensive Pisonia grandis forest. Although Pisonia has high invertebrate leaf counts (Hill 2002), it also produces sticky fruits that can cause mortality in seabirds (e.g. Penny 1974). Currently there is no evidence that this also occurs with small endemic passerines e.g. Seychelles Warbler, Sunbird or Fody. However, male flycatchers have tails up to $30 \mathrm{~cm}$ long, and since individuals feed mid-canopy (Watson 1991, Currie 2002), caution should be exercised at this time in recommending translocating the flycatcher to islands with extensive Pisonia forest. Bird also has crazy ants Anoplolepis gracilipes, an introduced invasive ant species, which has profound impacts on forest habitats (Hill et al. in press b), invertebrates (Haines et al. 1994) and vertebrates (Feare 1999), whilst on Cousin there is the potential impact, albeit speculative, of Seychelles Fody, a potential nest predator of passerine eggs (e.g. Veen et al. 2000), on the breeding success of a small translocated population.

In August 1999, eradication of alien predators was conducted on three islands: Denis, Curieuse and Frégate (Millett and Shah 2001). In light of the area of suitable habitat and their presumed rat and cat free status, Denis and Curieuse islands were identified as the most suitable for flycatchers (Nature Seychelles and Seychelles Government unpubl.). Subsequently rats were found to be present on both islands (Nature Seychelles unpubl.) and proposed translocations were postponed. Future rat eradications are proposed for 2002-2003, including North and Denis. However, there is no guarantee that rat-free status will be achieved and/or maintained. The success of these eradications could not be judged until 18 months after the operation, so the earliest that birds could safely be moved to these islands would be 2004 .

\section{The importance of predators (all islands): assessing the risks}

The fact that flycatchers can coexist with alien predators is not at issue: the La Digue population has increased twofold in the last 12 years (Watson 1991, Rocamora 1997) in the presence of a suite of both native and introduced species. The argument that is more frequently overlooked is whether a translocated population, which by definition would be small and potentially vulnerable, could establish with the additional pressure posed by predators and ultimately become selfsustaining. Two major reasons that have been attributed to failed translocation of birds are (i) the presence of predators and (ii) the use of a small founder population (Lovegrove 1996).

Recent new data on adult and juvenile survivorship and breeding success on La Digue plateau indicate that a small translocated population (c. 10-20 pairs) could persist in the presence of predators, but population growth would be small (Currie 2002). It might be possible to facilitate population growth under these conditions by transferring a larger number of birds to offset lower breeding success and adult mortality, accompanied by intensive predator management, in 
particular the effective control and/or exclusion (as opposed to their eradication) of alien and possibly some native predators (e.g. Robertson et al. 1994). However, despite the revised population estimate for La Digue of more than 200 individuals (Currie 2002) there is still a limited number of birds that could be moved without threatening the source population.

Ideally it would be preferable to conduct initial translocations of the flycatcher to predator-free islands. However, currently there are only five islands $>20$ ha which are rat, cat and bulbul free in the inner Seychelles: Cousine ( $25 \mathrm{ha})$, Cousin (27 ha), Aride (68 ha), Bird (101 ha), and Frégate (219 ha), but all lack extensive areas of habitat of demonstrated suitability, and none are considered a priority to receive the flycatcher. Aride has been suggested as suitable for the flycatcher (e.g. Gerlach 1997, Skerrett et al. 2001), but the estimated population would be small (c. 5 pairs; see also Gerlach 1997), which would be of limited conservation value.

In light of the restrictions predator-free status imposes on the options to establish new island populations, the apparent tolerance of flycatchers to alien (and native) predators, and the continued (and future) habitat degradation on $\mathrm{La}$ Digue, a radical rethink of flycatcher translocation options may be required, considering (i) translocation to suitable medium-sized islands with limited predator fauna and/or (ii) translocation to a large island with extensive populations of alien and native predators.

Currently there are two suitable medium-sized islands with limited predator fauna: Curieuse and Denis, both of which only have the black rat. Curieuse would require habitat restoration prior to translocation. Denis on the other hand has recently undergone significant habitat restoration and currently has c. 30 ha of high-canopy Badamier-dominated plateau forest, which is expected to increase to $c .35$ ha in the next 5 to 10 years.

Although multiple individual populations on small and medium-sized islands could eventually equate in importance to the La Digue population, each would be potentially vulnerable. Creation of a second large population (more than 50 pairs) is therefore ultimately the best option to improve the flycatcher's conservation status. The only way to achieve this is to transfer individuals to one of the larger islands with a greater area of suitable habitat than currently available on medium-sized islands. Extreme predator control measures would also have to be targeted against a suite of predators: large islands support extensive populations of native and alien adult and/or nest predators. In the absence of extensive data on the quantitative effects of individual predator species, control measures would necessarily be implemented on all species with the potential to be detrimental to the flycatcher. More birds would probably also have to be translocated to offset any adult mortality in the 12 months prior to the first recruits coming into the population. This is a high-risk strategy requiring extensive ongoing commitment and resources to ensure success of such an ambitious undertaking $(5-10$ years involving predator control, habitat management and monitoring following objectives clearly stated in a stakeholder-agreed management plan), and could only be attempted on islands with sufficient habitat to support a large, resilient population of birds.

Two large islands have significant areas of native broad-leaved forest suitable for the flycatcher, and which have larger areas of suitable habitat than currently 
available on suitable medium-sized islands. These are Praslin (e.g. Cote d'Or and Anse Kerlan), and Silhouette (Grande Barbe and surrounding area; Gerlach 1997). Of these two islands Silhouette, although not in the flycatcher's historical range, would initially appear to be the better option, as it has fewer people and the island is managed by a government parastatal (Island Development Corporation; IDC). However, a critical re-evaluation of these large islands is needed; particularly of habitat suitability for supporting a large population and future development plans, thus avoiding the situation on la Digue where conservation policy is severely constrained by development pressures.

\section{Conclusions}

Current and future levels of development on La Digue, especially on the western plateau, would appear to be inconsistent with any significant future improvements in the flycatcher's conservation status, due to the limitations that development (compounded by multiple land ownership) imposes on population expansion. Establishment of new populations should therefore be considered a priority.

The primary predictor determining island suitability for creation of additional populations of the flycatcher, based on observations of the La Digue population, would appear to be the presence of (native) high-canopy forest, characteristically found on coastal plateau, but also on sheltered low and mid-slopes. Secondary considerations are the presence of predators (both alien and native) and wetland areas. This conservative plateau model ultimately imposes significant limitations on the options for translocation. Additional restrictions are placed on island selection by the species' biology; it is not possible to manage flycatchers directly, as for example with Seychelles Magpie-robin, where small populations can be maintained in low-quality habitat using intensive management (including supplementary feeding).

Three options currently exist for expanding the range of flycatcher by translocation. These are to create additional populations on: (i) suitable medium-sized predator-free islands (none of which are currently available, but may become available in 2004); (ii) a suitable medium-sized island with restricted predator fauna (of which there are currently two: Curieuse, with the proviso of habitat restoration, and Denis); and/or (iii) translocation to a large island with a suite of predator species (Praslin or Silhouette) accompanied by appropriate and rigorous management practices to facilitate both adult and nest survival. There are currently no data on responses of individuals to translocation and it would therefore be prudent to consider options (i) or (ii) at this time before attempting more ambitious translocations. However, ultimately, the translocation of individuals to another large island may prove the best option for significantly increasing numbers and ultimately securing the long-term future of the flycatcher. In the meantime, the importance of the La Digue population cannot be overemphasized and the continued management and conservation of the remaining native broadleaved (plateau) forest on this island should be considered the highest priority.

\section{Acknowledgements}

We thank the residents of La Digue, the Ministry of Transport and Environment and the Ministry of Land-Use and Habitat for their cooperation, and Kerstin 
Henri (Project Coordinator) and Michele Martin (Education Coordinator) from Nature Seychelles for their logistical support during the study. This research was funded as part of the GEF/World Bank-funded Seychelles Restoration of Avian Ecosystems Project implemented by Nature Seychelles. Clive Hambler, Jeff Watson and Tony Diamond provided useful comments on an earlier version of this manuscript.

Appendix 1. Mean number of invertebrates on foliage $\left(\mathrm{m}^{2}\right)$ excluding ants and soft bugs (calculated after Hill 2001) on Takamaka Calophyllum inophyllum and Badamier Terminalia catappa 19992000, all native tree species (excluding Morinda) and non-native tree species in the north-west (NW) and south-east (SE) monsoons. Data in parentheses gives equivalent values for La Digue sampled in same months.

\begin{tabular}{llllll}
\hline Island & Season & Takamaka & Badamier & Natives & Non-natives \\
\hline Bird & $\mathrm{NW}$ & - & - & 39.89 & 19.95 \\
\multirow{3}{*}{ Conception } & $\mathrm{SE}$ & - & - & - & - \\
& $\mathrm{NW}$ & $0.86(8.83)$ & - & 5.07 & 1.42 \\
Cousin & $\mathrm{SE}$ & $5.94(4.93)$ & - & 6.65 & 6.65 \\
& $\mathrm{NW}$ & - & - & 25.88 & - \\
Curieuse & $\mathrm{SE}$ & - & - & 49.76 & - \\
& $\mathrm{NW}$ & $2.85(8.83)$ & $0.49(5.81)$ & 5.45 & 3.57 \\
Denis & $\mathrm{SE}$ & $9.65(9.61)$ & $5.55(4.75)$ & 5.09 & 9.39 \\
& $\mathrm{NW}$ & $10.26(6.21)$ & $10.50(5.11)$ & 11.54 & 4.07 \\
Félicité & $\mathrm{SE}$ & $2.08(4.95)$ & $3.08(2.80)$ & 4.68 & - \\
& $\mathrm{NW}$ & - & - & - & - \\
Grand Soeur & $\mathrm{SE}$ & $2.08(4.95)$ & - & 2.17 & 4.57 \\
\multirow{2}{*}{ Marianne } & $\mathrm{NW}$ & - & - & - & - \\
\multirow{4}{*}{ North } & $\mathrm{SE}$ & $13.41(9.61)$ & $6.64(4.75)$ & 5.64 & 9.0 \\
& $\mathrm{NW}$ & $5.52(6.21)$ & $5.80(5.11)$ & 8.21 & 16.56 \\
\multirow{2}{*}{ Therese } & $\mathrm{SE}$ & $4.12(4.77)$ & $2.79(3.47)$ & 8.01 & 6.83 \\
& $\mathrm{NW}$ & $11.49(8.83)$ & - & 10.48 & 7.18 \\
& $\mathrm{SE}$ & $5.61(4.95)$ & $4.83(2.82)$ & 7.49 & 4.95 \\
\hline
\end{tabular}

\section{References}

Atkinson, I. A. E. (1985) The spread of commensal species of Rattus to oceanic islands and their effects on island avifaunas. Pp. $35^{-81}$ in P. J. Moors, ed. Conservation of island birds. Cambridge, U.K.: International Council for Bird Preservation.

Beamish, T. (1972) The Paradise-flycatcher, Seychelles. Biol. Conserv. 4: 311-313.

Bell, B. D. (1978) The big south Cape Islands rat irruption. Pp. 7-31, in P. R. Dingwell, I. A. E. Atkinson and C. Hay, eds. The ecology and control of rodents in New Zealand Nature Reserves. Wellington: New Zealand Department of Lands and Survey (Information Series 4).

BirdLife International (2000) Threatened birds of the world. Barcelona and Cambridge, U.K.: Lynx Edicions and BirdLife International.

Bowler, J. and Hunter, J. (2000) Aride Island nature reserve report 1999. The Kiln, Newark, U.K.: R.S.N.C.

Bullock, I. D., Komdeur, J. G., Komdeur, M. D., Laboudallon, V. and Lewis, G. (1988) The Seychelles Black Paradise-flycatcher Terpsiphone corvina. Report to ICBP.

Collar, N. J. and Stuart, S. N. (1985) Threatened birds of Africa and related islands. Cambridge, U.K.: ICBP and IUCN 
Currie, D. (2002) Ecological requirements of the Seychelles Black Paradise-flycatcher Terpsiphone corvina: consequences for conservation and management. Victoria, Mahé: BirdLife Seychelles.

Currie, D., Bristol, R., Millett, J., Hill, M., Bristol, U. , Parr, S. J. and Shah, N.J. (in press) Habitat requirements of the Seychelles Black Paradise-flycatcher Terpsiphone corvina: a re-evaluation of translocation priorities. Ibis.

Diamond, A. W. (1984) Biogeography of Seychelles land birds. Pp. 487-504 in D. R. Stoddart, ed. Biogeography and ecology of the Seychelles Islands. The Hague/Boston/Lancaster: Dr W. Junk Publishers (Monographiae Biologicae 55).

Feare, C. J. (1999) Ants take over from rats on Bird Island, Seychelles. Bird Conserv. Internatn. 9: 95-96.

Gaymer, R., Blackman, R. A. A., Dawson, P. G., Penny, M. and Penny C. M. (1969) The endemic birds of Seychelles. Ibis 111: 157-176

Gerlach, J. ed. (1997) Seychelles Red Data Book. Seychelles: The Nature Protection Trust of Seychelles.

Grieg-Smith PW. (1980) Foraging, seasonality and nesting of Seychelles Sunbirds Nectarinia dussumieri. Ibis 121: 307-321.

Griffith, B., Scott, J. M., Carpenter, J. W. and Reed, C. (1989) Translocation as a species conservation tool: status and strategy. Science 245: 477-486.

Haines, I. H., Haines, J. B. and Cherrett, J. M., (1994) The impact and control of the crazy ant Anoplolepis longipes (Jerd.) in the Seychelles. Pp. 206-218 in D. F. Williams, ed. Exotic ants: biology, impact and control of introduced species. Boulder, CO: Westview Press.

Hambler, C. (1992) Habitat assessment for the Seychelles Black Paradise-flycatcher invertebrate counts, University of Oxford, unpublished report.

Hill, M. J. ed. (2002) Biological assessments of islands in the granitic Seychelles. Atoll Ress Bull. 495 (special issue).

Hill, M. J, Currie, D. and Shah, N. J. (in press a) The impacts of vascular wilt disease of Takamaka Calophyllum inophyllum L. on conservation value of islands in the granitic Seychelles. Biol. Conserv.

Hill, M J., Vel, T. and Shah, N. J. (in press b) The impact of an introduced invertebrate on conservation: crazy ant Anoplolepis gracilipes (Smith 1857) on Bird Island, Seychelles.

IUCN (1998) IUCN guidelines for re-introductions. Gland, Switzerland and Cambridge, U.K.: IUCN/SSC Re-introduction Specialist Group, IUCN.

Ivory, M. H. and Andre, W. (1994) A preliminary report of Verticillium wilt of Takamaka (Calophyllum inophyllum L.) in Seychelles. Afr. J. Mycol. Biotechnol. 3: 169-170.

Ivory, M. H., Andre, W. and Vielle, M. (1996) Wilt of Takamaka (Calophyllum inophyllum L.) in Seychelles. Phelsuma 4: 43-47.

Johnson, D. N. and Herremans, M. (1997) Paradise-flycatcher Terpsiphone viridis. Pp. 371372 in J. A. Harrison, D. G. Allan, L. G. Underhill, A. J. Tree, V. Parker and C. J. Brown, eds. The atlas of southern African birds, 2: Passerines. Johannesburg: BirdLife South Africa.

King, B., Woodcock, M. and Dickinson, E. C. (1993) Birds of south-east Asia. London: Harper Collins.

Komdeur, J., Bullock, I., D. and Rands, M. R. W. (1991) Conserving the Seychelles Warbler Acrocephalus sechellensis by translocation: a transfer from Cousin Island to Aride Island. Bird Conserv. Internatn. 1: 177-185

Lovegrove, T. G. (1996) Island releases of Saddlebacks Philesturnus carunculatus. New Zealand. Biol. Conserv. 77: 151-157.

Marshall, S. S. (1997) Future mangement priorities for the Black Paradise-flycatcher (Terpsiphone corvina), La Digue, Seychelles MSc thesis, University of Edinburgh.

Mayfield, H. (1961) Nesting success calculated from exposure. Wilson Bull. 73: 255-261.

Mayfield, H. (1975) Suggestions for calculating nesting success. Wilson Bull. 87: 456-466.

Merton, D. V. (1975) The Saddleback: its status and conservation. Pp. 61-74 
in R. D. Martin ed. Breeding endangered species in captivity. London: Academic Press.

Merton, D. V. (1978) Controlling introduced predators and competitors on islands. Pp. 121-127 in S. A. Temple, ed. Endangered birds: management techniques for preserving threatened species. Madison, WI: The University of Wisconsin Press.

Millett, J. (2001) Rats loss is Magpie-robins gain. World Birdwatch 23(2): 20-23.

Millett, J. and Shah, N. J., eds. (2001) Seychelles Magpie-robin recovery programme review of progress 2000. Victoria, Mahé: Nature Seychelles.

Neufeld, D. (1998) Nest site use and changes in habitat of the Seychelles Black Paradiseflycatcher Terpsiphone corvina. Biol. Conserv. 84: 103-105.

Newton, E. (1867) On the land birds of the Seychelles archipelago. Ibis (2) 5: 335-360.

Nicoll, M. J. (1906) On the birds collected and observed during the voyage of the Valhalla. Ibis (8): $66-712$

Njoroge, P. (2002) The Seychelles Magpie-robin Copsychus sechellarum: territory quality, demography and conservation of a threatened species. Ph.D. thesis, University of Reading.

Parr, S. J., Shah, N. J. and Millett, J. E., eds. (2000) Seychelles magpie-Robin recovery programme. Review of progress 1999. Victoria, Mahé: BirdLife Seychelles.

Parr, S. J. and Shah, N. J. (1998) Recolonisation of Marianne island by Seychelles Paradiseflycatcher after 60 years. Bull. Afr. Bird Club 5(2): 90

Penny, M. (1974) Birds of the Seychelles. Fifth edition. London: Collins.

Robertson, H. A., Hay, R. J., Saul, E. K. and McCormack, G. V. (1994) Recovery of the Kakerori: an endangered forest bird of the Cook Islands. Conserv. Biol. 8: 1078-1086.

Rocamora, G. (1997) Rare and threatened species, sites and habitat monitoring programme in Seychelles. Project Gı EMPS. Division of Environment/BirdLife International.

Rocamora, G. and François, J., eds. (2000) Seychelles White-eye recovery programme. Results from phase I. Report to Ministry of Environment and Transport/IUCN/Dutch Trust Fund. Seychelles.

Rocamora, G. and Skerrett, J. (2000) Seychelles. Pp. 751-768 in L. C. D. Fishpool and M. I. Evans, eds. Important bird areas in Africa and associated islands: priority sites for conservation. Newbury and Cambridge, U.K.: Pisces Publications and Birdlife International (BirdLife Conservation Series 11).

Shah, N. J. (1995a) La Veuve Special Reserve management plan. Mahé, Seychelles: Division of the Environment/World Conservation Union (IUCN).

Shah, N. J. (1995b) On the trail of a mystery disease. Tropical Forest Update: Newsletter of the International Tropical Timber Organisation 5(4):20.

Shah, N. J. (1996) Environmental Impact Assessment of the La Digue Solid Landfill Site. Mahé, Seychelles: Division of the Environmental/European Union.

Skerrett, A., Bullock, I. and Disley, T. (2001) Birds of Seychelles. London: Christopher Helm, A \& C Black.

Stattersfield, A., Crosby, M. J., Long, A. J. and Wege, D. C. (1998) Endemic bird areas of the world: priorities for biodiversity and conservation. Cambridge, U.K.: BirdLife International (BirdLife Conservation Series 7).

Stevenson, A., Purse, B. and Lund, J. (1997) Assessment of the invertebrate feeding sources of the Seychelles Black Paradise-flycatcher: a comparison between existing territories on La Digue and a potential introduction site on Curieuse. Pp. 37-43 in A. Stevenson, B. Purse, B. and J. Lund, eds. A comparative survey of wetlands. Report of the Oxford University Seychelles Expedition.

Thorsen, M., Shorten, R., Lucking, R. and Lucking, V. (2000) Norway rats (Rattus norvegicus) on Frégate Island, Seychelles: the invasion; subsequent eradication attempts and implications for the island's fauna. Biol. Conserv. 96: 133-138.

Veen, T., Richardson, D. S., Blaakmeer, K. and Komdeur, J. (2000) Experimental evidence 
for inanate predator recognition in the Seychelles warbler. Proc. R. Soc. Lond. B 267: $2253-2258$.

Vesey-Fitzgerald, D. (1936) Birds of the Seychelles and other islands included in that colony. Seychelles Government Printer.

Vesey-Fitzgerald, D. (1940) The birds of Seychelles. I. The endemic birds. Ibis (14) 4: 480489.

Walsh, R. P. D. (1984) Climate of the Seychelles. Pp. 39-62 in D. R. Stoddart, ed. Biogeography and ecology of the Seychelles islands. The Hague/Boston/Lancaster: Dr W. Junk Publishers (Monographiae Biologicae 55).

Wainhouse, D., Murphy, S., Greig, B., Webber, J. and Vielle, M. (1998) The role of the bark beetle Crphalus trypanus in the transmission of the vascular wilt pathogen of the Takamaka (Callophylum inophyllum L.) in the Seychelles. Forest Ecol. and Manage. 108: 193199

Watson, J. (1981) The Seychelles Black Paradise-flycatcher on La Digue 1977-78. WWF Project 1590, final report.

Watson, J. (1984) Land birds: endangered species on the granitic Seychelles. Pp. 513-527 in D. R. Stoddart, ed. Biogeography and ecology of the Seychelles Islands. The Hague/Boston/ Lancaster: Dr W. Junk Publishers (Monographiae Biologicae 55).

Watson, J. (1988) The Seychelles Paradise-flycatcher on La Digue: population size, habitat requirements and management options. ICBP unpublished report.

Watson, J. (1991) The Seychelles Paradise-flycatcher on La Digue: population size, habitat requirements and management options. Bird Conserv. Internatn. 1: 107-122.

DAVE CURRIE, MIKE HILL, JAMES MILLETT, RACHEL BRISTOL and NIRMAL J. SHAH

Nature Seychelles, P.O. Box 1310, Victoria, Mahé, Republic of Seychelles.

E-mail: nature@seychelles.net

\section{JOHN NEVILL}

Ministry of Environment and Conservation, Botanic Gardens, Mont Fleuri, Mahé, Republic of Seychelles

Received 24 August 2001; revision accepted 13 December 2002 